\title{
PERENCANAAN PARTISIPATIF DENGAN PENDEKATAN FENOMENOLOGI DI DISTRIK KOMBUT KABUPATEN BOVEN DIGOEL
}

\author{
Arius Kambu ${ }^{1}$ \\ ariusk16@gmail.com
}

\begin{abstract}
This study aims to describe and analyze participatory planning processes as well as describe the representation of all stakeholders in participatory planning in Kombut District of Boven Digoel Regency. This research is a qualitative research with phenomenology approach and data collection technique done by field observation, interview, document review and literature review and empirical study. Informants in this study are village officials and community leaders. Research findings related to participatory planning revealed that the implementation of village-level development planning more done in formalities and not all stakeholder components are fully involved in the implementation of village level meetings and still found the government dominance in setting the program. While other findings related to participatory planning in community infrastructure development participate because there is income or wages earned to look reasonable but also at the same time apprehensive, on the other hand the government is considered failed in increasing community participation. Here, positive findings of participation can be said either that the community has been sensitive to the phenomenon and the reality that is happening around them, and even has provided input to the government for it.
\end{abstract}

\section{Keywords: Participatory Planning}

\section{PENDAHULUAN}

Penyelenggaraan pelayanan pubik yang dilakukan pemerintah daerah selama ini didasarkan pada pendekatan legalitas. Dalam menyusun, merumuskan dan menetapkan kebijakan senantiasa didasarkan pada pendekatan prosedur dan keluaran (out put), serta dalam prosesnya berlindung pada peraturan perundangundangan atau mendasarkan pada pendekatan legalitas. Penggunan paradigma pendekatan legalitas, dewasa ini cenderung mengedepankan prosedur, hak dan kewenangan atas urusan yang dimiliki (kepentingan pemerintah daerah), dan kurang memperhatikan prosesnya. Pengertiannya, dalam proses merumuskan, menyusun dan menetapkan kebijakan, kurang optimal melibatkan stakeholders (pemangku kepentingan di lingkungan birokrasi, maupun masyarakat).

Pelayanan publik menurut paradikma good governance, dalam proses tidak hanya dilakukan pemerintah daerah berdasarkan pendekatan legalitas, atau hanya untuk kepentingan pemerintah daerah, good governance mengedepankan proses dan prosedur, dimana proses persiapan, perencanaan, perumusan dan

${ }^{1}$ Staff Pengajar Jurusan Manajemen Fakultas Ekonomi \& Bisnis Universitas Cenderawasih Papua 
penyusunan suatu kebijakan senantiasa mengedepankan kebersamaan dan dilakukan dengan melibatkan seluruh pemangku kepentingan.

Pembangunan merupakan sebuah proses pengembangan kapasitas masyarakat dalam jangka panjang sehingga memerlukan perencanaan yang tepat dan akurat. Perencanaan ini berarti harus mampu mencakup kapan, dimana dan bagaimana pembangunan harus dilakukan agar mampu merangsang pertumbuhan ekonomi secara berkesinambungan. Dengan kata lain, pembuat rencana pembangunan haruslah mampu untuk memprediksi dampak yang ditimbulkan dari pembangunan yang akan dilakukan baik dalam jangka pendek maupun dalam jangka panjang.

Dikaitkan dengan Dana Desa (DD) dan otonomi khusus sebenarnya perencanaan partisipatif merupakan peluang baik bagi daerah menunjukan kinerjanya untuk meningkatkan kesejahteraan masyarakat di wilayahnya, termasuk upaya menuju perwujudan good local governance.

Penyusunan dokumen perencanaan pembangunan di Boven Digoel dilakukan dengan menggunakan pendekatan perspektif. Pendekatan perspektiff dilakukan dengan cara pemerintah daerah menyusun rencana program/kegiatan pembangunan yang dianggap sangat dibutuhkan masyarakat untuk meningatkan kesejahteraan mereka. Berikut, Alexander Abe (2002) menjelaskan perencanaan berasal dari kata rencana, yang berarti rancangan atau rangka sesuatu yang akan dikerjakan. Dari pengertian sederhana tersebut dapat diurai beberapa kompenen penting, yakni tujuan (apa yang hendak dicapai), kegiatan (tindakan-tindakan untuk merealisasi tujuan), dan waktu (kapan, bilamana kegiatan tersebut hendak dilakukan). Apa yang direncanakan tentu saja merupakan tindakan-tindakan masa depan (untuk masa depan) Dengan demikian suatu perencanaan bisa dipahami sebagai respon (reaksi) terhadap masa depan.

Pengamatan dilakukan pada saat proses penyusunan RPJMKampung se Kabupaten Boven Digoel ditemukan beberapa persoalan mendasar sebagai berikut : (1) Proses perencanaan partisipasi melalui mekanisme musrembang di distrik masih menjadi retorika. Dikarenakan aktor yang paling penting dan dominan dalam penyusunan formulasi perencanaan pembangunan di distrik adalah pemerintah daerah bukan masyarakat Kombut. Proses musrembang di Distrik Kombut hanya berisis kegiatan berupa paparan dari instansi teknis. Peserta hanya diberikan kesempatan untuk bertanya mengenai seputar kegiatan-kegiatan tersebut tidak ada diskusi antara pemerintah daerah dengan peserta tentang issuissu atau permasalahan serta pemecahan masalah; (2) Kualitas dokumen perencanaan yang dihasilkan pada kegiatan musrembang rendah dan kurang 
sistematis. Hanya berisi rekapitulasi dari hasil musrembang yang berisi kegiatan dan dana yang dibutuhkkan. Dari segi tujuan, cara untuk merealisasi kegiatankegiatan dan waktu secara rinci tidak dijelaskan; (3) Stakeholder tidak terwakilkan secara menyeluruh dalam musrembang Distrik Kombut; (4) Partisipasi masyarakat dalam proses penyusunan kebijakan publik telah banyak dilakukan diantaranya oleh Cooper dan Elliot, 2000; Layzer, 2002; Navaro, 2002; Adams; 2004. Hasil penelitian tersebut menunjukkan bahwa partisipasi masyarakat masih rendah. Hal ini ditunjukkan dengan rendahnya tingkat kehadiran mereka dalam berbagai temu publik. Temu publik dianggap kurang efektif sebagai alat persuasi rasional, namun demikian temu publik ini tetap berperan untuk memelihara sistem demokrasi lokal. Tujuan penelitan mendeskripsikan dan menganalisis proses perencanaan partisipatif dan keterwakilan stakeholder di Distrik Kombut Kabupaten Boven Digoel.

Perencanaan, Menurut Conyers dan Hills (1994), Moekijat (1980), Koontz dan Cyrill O. Donell dalam Sarmoto, (1987:66), Watterson dalam Tjokroamidjojo (1985:16) dalam teori masing-masing pada intinya menjelaskan bahwa dengan memahami pengertian perencanaan dan keterkaitannya dengan masalah-masalah pembangunan, maka antar aspek perencanaan dan pembangunan selalu terkait, dan mempunyai hubungan internalisasi serta kasualitas, yang ditekankan pada penentuan strategi, rencana dan kebijaksanaan pembangunan diimplementasikan ke dalam bentuk program dan proyek pembangunan sehingga tujuan pembangunan dapat dicapai secara efisien dan efektif.

Administrasi, Siagian (2001:38), Kerlinger dalam Pasolong (2011:9), Pasolong (2011:10), A. Dunsire yang dikutip ulang oleh Keban (2008:2), para pengarang memberi gambaran secara umum administrasi dalam arti sempit ini sebenarnya lebih tepat disebut dengan tata usaha. Sedangkan administrasi dalam arti luas adalah kegiatan kerja sama yang dilakukan sekelompok orang berdasarkan pembagian kerja sebagaimana ditentukan dalam struktur dengan mendayagunakan sumber daya untuk mencapai tujuan secara efektif dan efesien. Pengertian administrasi dalam arti luas memiliki unsur-unsur sekelompok orang, kerja sama, pembagian tugas secara terstruktur, kegiatan yang runtut dalam proses, tujuan yang akan dicapai, dan pemanfaatan berbagai sumber.

Definisi Negara, Max Weber (1946), Robert Maclver (1926, Roger H. Soltau (dalam Budiarjo, 2008: 48), Frederickson, Wayne Parson (2008) dan Parson (2008: 6) para penulis mendefinisikan negara merupakan sebuah asosiasi atau perkumpulan pada suatu willayah yang bertanggung jawab melaksanakan 
penertiban masyarakat yang berasaskan sistem hukum yang telah ditetapkan pemerintah yang sifatnya memaksa.

Partisipasi, John M. Echols \& Hasan Shadily, 2000: 419), I Nyoman Sumaryadi, (2010: 46). Fasli Djalal dan Dedi Supriadi, (2001: 201-202), H.A.R.Tilaar, (2009 : 287) menjelaskan teori partisipasi berarti peran aktif masyarakat dalam proses pembangunan baik dalam bentuk materi maupun non materi serta memanfaatkan atau menikmati hasil pembangunan yang telah dicapai.

\section{METODE PENELITIAN}

Dalam penelitian ini menggunakan pendekatan fenomenologi. Melalui pendekatan ini penulis ingin mengukur secara kualitatif perencanaan partisipati dan keterlibatan stakeholder dalam proses perencanan pembangunan tingkat distrik kombut namun tujuan utamanya adalah pemahaman mendalam mengenai partisipati masyarakat dengan menggunakan metode pengumpulan data yang digunakan pada penelitian kualitatif seperti wawancara mendalam, pengamatan lapangan, serta analisis dokumen. Berdasarkan dimensi waktu penelitian ini termasuk dalam cross-sectional research. Dalam penelitian ini data primer yang diguanakan berasal dari informasi yang diperoleh langsung dari masyarakat pemilik hak ulayat. Data sekunder diperoleh dari buku, jurnal penelitian, media internet dan catatan.

\section{HASIL DAN PEMBAHASAN}

\section{Perencanaan Partisipatif Dalam Penyusunan Program Pembangunan}

Partisipasi masyarakat pada penyusunan program pembangunan di Distrik Kombut berdasarkan hasil pemotretan lapangan ketika penyusunan RPJMK dapat dikategorikan kurang baik. Hal ini dilihat dari belum adanya sosialisasi yang dilakukan pemerintahan tingkat Distrik serta belum adanya pedoman di Distrik sebagai acuan dalam pelaksanaan partisipatif, kurangnya pelibatan masyarakat dalam proses perencanaan pembangunan partisipatif yang dilakukan sejak adanya pemekaran empat kampung menjadi satu distrik dipecahkan dari distrik induk Mindiptana. Masyarakat Kombut umumnya telah mengerti dan memahami perencanaan partisipatif. Musrembang kampung belum menjadi wadah yang handal bagi masyarakat untuk dapat menyelesaikan permasalahan pembangunan perluasan akses layanan publik. Selama ini musrembang kampung hanyalah sebagai formalitas saja, keputusan-keputusan tentang program atau kegiatan 
pembangunan tetap berasal dari pemerintah Daerah yang jarang sekali memperhatikan hasil musrembang kampung itu sendiri. Hasil pengamatan lapangan ini sebagaimana juga digambarkan dalam penelitian dari FIKB Universitas Indonesia (2002:102) yang mengukur partisipasi masyarakat dalam pembangunan daerah dengan "delapan tangga partisipasi masyarakat" (eight rungs on the leader of citizen participation) dari Arstein, menjelaskan bahwa di sebagian besar Daerah partisipasi masyarakat baru terjadi sebatas partisipasi semu. Dari kecenderungan yang ada, partisipasi masyarakat di daerah lebih banyak di dominasi oleh elit daerah. Pokok pikiran yang penting dari hasil kajian tersebut, menunjukkan bahwa partisipasi masyarakat sampai dengan saat ini lebih banyak sebagai proses mobilisasi kepentingan tertentu saja. Masyarakat akan diikut sertakan sebatas dalam sebuah tahapan perencanaan. Itupun sekedar diminta pendapatnya dalam sebuah forum yang sudah di seting sebelumnya. Masyarakat dilibatkan hanya sebatas dalam musyawarah di tingkat desa, kecamatan serta proses penjaringan aspirasi masyarakat. Setelah itu, terutama dalam proses penetapan dan pengambilan keputusan, masyarakat tidak memiliki akses sedikitpun. Termasuk dalam melakukan koreksi atas penetapan kebijakan tersebut. Permasalahan yang terkait bahwa proses musrenbang desa hanya "sekedar formalitas" bukan hanya di Jawa, tetapi di Luar Jawa pun demikian sebagaimana yang diungkap oleh hasil penelitian Razak (2011) dan Ridwan (2012). Razak (2011) yang menyatakan bahwa masyarakat sebagai stakeholders merasa dan menilai dirinya hanya sebagai objek partisipasi, bukan sebagai subjek partisipasi. Subjek partisipasi tetap saja didominasi oleh kelompok-kelompok elit dari pihak eksekutif dan legislatif maupun kelompok kepentingan lainnya. Kebijakan partisipatif seperti musrenbang hanya dijadikan "medan magnit" sebagai simbol dari arti penting partisipasi. Simbol ini sebagai bentuk pelibatan partisipasi masyarakat dalam perencanaan pembangunan dan penyusunan anggaran yang lebih menekankan pada prosedur administrasi kehadiran. Pelibatan ini lebih menggambarkan formalitas atau kegiatan seremonial belaka, karena masyarakat yang terlibat banyak tidak mengetahui esensi dari mekanisme perencanaan dalam bentuk Musrenbang. Sementara, Ridwan (2012) yang menjelaskan bahwadijadikan "medan magnit" sebagai simbol dari arti penting partisipasi. Simbol ini sebagai bentuk pelibatan partisipasi masyarakat dalam perencanaan pembangunan dan penyusunan anggaran yang lebih menekankan pada prosedur administrasi kehadiran. Pelibatan ini lebih menggambarkan formalitas atau kegiatan seremonial belaka, karena masyarakat yang terlibat banyak tidak mengetahui esensi dari mekanisme perencanaan dalam bentuk Musrenbang. 
Hasil penelitian Cooper dan Elliot (2000) menjelaskan mekanisme partisipasi dan evaluasi efektifitas partisipasi masyarakat dalam perencanaan dan pelaksanaan pembangunan. Menggunakan metode studi kasus di tiga program pembangunan, ditemukan hasil bahwa pemanfaatan peluang yang ada dalam partisipasi masyarakat bergantung pada kemampuan mengevaluasi efektivitas partisipasi masyarakat. Manfaat positif partisipasi masyarakat banyak diperoleh dari adanya akseptabilitas sosial. Sedangkan Layzer (2002) yang menguji hipotesis bahwa pengambilan keputusan secara partisipatif menghasilkan solusi yang berkelanjutan dibandingkan dengan proses pembuatan kebijakan secara konvensional. Berikutnya, hasil kajian Lurian (2004) terfokus pada faktor yang mendorong partisipasi masyarakat bagi pengambilan keputusan dalam pembangunan pemerintah daerah. Penelitian dengan menggunakan metode survey dan dianalisis secara deskriptif menghasilkan bahwa ketidakhadiran anggota kelompok dalam suatu pertemuan dibatasi oleh kurang sadarnya bahwa kegiatan itu sebagai gerakan bersama. Motivasi merupakan faktor kunci yang mempengaruhi seseorang untuk berpartisipasi. Selanjutnya Irvin dan Stansbury (2004) menunjukkan bahwa efektivitas partisipasi masyarakat sebagai alat pembuatan kebijakan. Hasilnya menunjukkan bahwa terdapat 5 kondisi partisipasi masyarakat sebagai alat pembuatan kebijakan yaitu kondisi berbiaya rendah, kondisi sangat bermanfaat, kondisi tidak ideal, kondisi berbiaya tinggi dan kondisi kurang bermanfaat. Dijelaskan juga bahwa terjadi pemborosan sumber daya dalam proses pembuatan kebijakan jika dilakukan dalam kondisi masyarakat yang kurang ideal. Bryan dan White (2006) menyatakan bahwa partisipasi dalam perencanaan dan pelaksanaan program dapat mengembangkan kemandirian. Selain itu di usulkan pula perluasan konsep partisipasi tidak hanya mencakup proses perencanaan dan pelaksanaan, tetapi juga partisipasi dalam penerimaan manfaat. Aspek penerimaan manfaat merupakan pelengkap dari cakupan pada proses perencanaan dan pelaksanaan sehingga membawa manfaat yang lebih besar bagi masyarakat. Griesgraber dan Gunter (1996) menambahkan aspek yang lain yaitu evaluasi. Dengan demikian konsep partisipasi menjadi lebih luas, mulai dari aspek perencanaan, pelaksanaan, evaluasi, sampai penerimaan manfaat. Hal ini juga sesuai dengan pendapat yang disampaikan oleh Fasli Djalal dan Dedi Supriadi, (2001: 201-202) menjelaskan partisipasi dapat juga berarti bahwa pembuat keputusan menyarankan kelompok atau masyarakat ikut terlibat dalam bentuk penyampaian saran dan pendapat, barang, keterampilan, bahan dan jasa. Partisipasi dapat juga berarti bahwa kelompok mengenal masalah mereka sendiri, mengkaji pilihan mereka, membuat keputusan, dan memecahkan masalahnya. 
Kesediaan masyarakat untuk mengambil bagian perencanaa suatu program pembangunan adalah merupakkan indikasi adanya kemampuan awal dari masyarakat untuk berkembang secara mandiri. Dalam hubungannya dengan partisipasi. Tjokroamidjojo (1995:207) mengemukakan bahwa keterlibatan aktif atau partisipasi masyarakat tersebut dapat berarti keterlibatan dalam proses penentuan arah, strategi dan kebijakan pembangunan yang dilakukan pemerintah. Sebagaimana diperkuat juga dengan penjelasan Soetoomo, 2008 : 8) yang menyatakan bahwa :

Masyarakat perlu dilibatkan secara langsung bukan karena mobilisasi, melainkan sebagai bentuk partisipasi yang dilandasi oleh kesadaran. Dalam proses pembangunan, masyarakat tidak semata-mata diperlakukan sebagai obyek, tetapi lebih sebagai subyek atau aktor atau pelaku.

Pentingnya keterlibatan masyatakat di dalam penyusunan perencanaan pembanggunan juga ditekankan dalam undang-undang Nomor 25 tahun 2004 tentang Sistem Perencanaan Pembangunan Nasional Pasal 2 Ayat (4) point (d) yang menyatakan bahwa :

Sistem Perencanaan Pembangunan Nasional bertujuan untuk mengoptimalkan partisipasi masyarakat. Lebih lanjut dijelaskan bahwa yang dimaksud dengan partisipasi masyarakat adalah keikutsertaan masyarakat untuk mengakomdasikan kepentingan mereka dalam proses penyusunan rencana pembangunan.

Berdasarkan uraian di atas maka dapat dijelaskan perencanaan pembangunan kampung-kampug di Distrik Kombut Kabupaten Boven Digoel Provinsi Papua akan tepat mengenai sasaran dan terlaksana dengan baik dan bermanfaat hasilnya jika dilaksanakan untuk memenuhi kebutuhan masyarakat sehingga perlu menempatkan masyarakat sebagai subjek pembangunan, bukan hanya sebagai obyek pembangunan. Selain memerlukan keterlibatan masyarakat, pembangunan juga membutuhkan strategi yang tepat agar dapat lebih efisien dari segi pembiayaan dan efektif dari segi hasil. Pemilihan strategi pembangunan ini penting dilihat karena Distrik Kombut Masuk dalam daerah terluar Indonesia yang berbatasan langsung dengan negara tetangga PNG yang tentunya memiliki sedikit perbedaan dengan kampung-kampung lain di Boven Digoel dalam hal pengembangan wilayahnya. Selain itu juga pemelihan strategi pembangunan ini penting karena akan menentukan dimana peran pemerintah dan dimana peran masyarakat, sehingga kedua pihak mampu berperan secara optimal dan sinergis.

Tumbuhnya partisipasi masyarakat dalam pembangunan kampung tidak terlepas dari adanya pemberian kesempatan untuk masyarakat terlibat dari adanya pemberian kesempatan untuk masyarakat terlibat secara langsung dalam 
setiap pengembilan keputusan menyangkut program kegiatan dan proyek pembangunan di kampung dan kemudian apabila dalam perjalanan pembangunan ada kegiatan-kegiatan yang direfisi perlu adanya pengambilan keputusan secara bersama-sama, maka masyarakat akan merasa bertanggung jawab dan akan ikut dalam pelaksanaan kegiatan pembangunan Kampung. Dengan demikian masyarakat akan merasakan bahwa hasil pembangunan yang dilaksanakan juga merupakan milik mereka sendiri, sehingga bila dituntut agar masyarakat menjaga hasil tersebut, maka dengan senang hati masyarakat akan menjaganya.

Secara emosional rang akan dengan senang hati mau menjaga memelihara, sesuatu yang mereka buat sendiri. Artinya jika mereka dilibatkan atau terlibat dalam perencanaan sampai pelaksanaan maka besar kemungkinan mereka pun akan dengan sukarela memanfaatkan dan menjaganya. Hanya dengan melibatkan sebanyak mungkin masyarakat sebagai subyek pembangunan maka keberlangsungan dari program atau kegiatan dan proyek pembangunan Kampung tersebut dapat terwujud dengan baik. Keterlibatan masyarakat sejak awal perencanaan sampai pada pelaksanaan kegiatan secagai bagian yang tidak terpisahkan dari peran serta masyarakat Kampung.

Faktor-faktor yang menghambat partisipasi masyarakat untuk ikut bersamasama dalam pembangunan kampung antara lain adalah : (1) terbatasnya fasilitas sarana dan prasarana yang ada; (2) tingkat penghasilan masyaakat; (3) timbul rasa ketidakpuasan masyarakat terhadap kinerja aparat pemerintah kampung; (4) perbedaan suku.

Selain faktor-faktor penghambat di atas, ada juga faktor pendukung yang dapat memberi dorongan masyarakat untuk ikut andil didalam proses pembangunan yakni antara lain : (1) Peran serta pemerintah kampung dalam mengarahkan warga masyarakat; (2) kesadaran masyarakat; (3) nilai budaya juga turut mempengaruhi.

Keterlibatan moral,, fisik maupun materi, adalah kepecayaan terhadap pemerintah dapat mengerjakan suatu sesuai dengan harapan masyarakat. Harus diakui secara empiris bahwa tingkat kepercayaan masyarakat masih harus ditingkatkan. Ketika masyarakat mempercayakan kepada pemerintah untuk mengelola dana masyarakat ternyata hasilnya kadang masih tidak sesuai harapan. Konsekuensinya kepercayaan warga masyarakat terhadap pemerintah akan menurun. Apabila pemerintah sudah tidak dpat dipercaya, maka agak sulit bagi pemerintah untuk menggerakkan masyarakat agar berpartisipasi langsung dalam berbagai program atau kegiatan pembangunan kampung yang berasal dari pemerintah. 
Pembangunan sebagai bagian dari kegiatan pemerintah adalah merupakan tanggung jawab antara pemerintah dan yang diperintah. Masyarakat sebagai kelompok terbesar suka ataupun tidak suka harus tetap bertanggung jawab terhadap seluruh aktivitas pembangunnan yang terjadi wilayahnya. Karena dampak dari semua itu tetap akan terpulang kepada masyarakat kempung sebagai penerima manfaat itu sendiri. Menurut Peraturan Pemerintah RI Nomor 72 Tahun 2005 tentang Desa pada Ketentuan Umum Pasal 1 Point 6, Pemerintahan Kampung adalah :

Penyelenggaraan urusan pemerintah oleh Pemerintah Desa/Kampung dan Badan Permusyawaratan Desan/Kampung (BPK) dalam mengatur dan mengurus kepentingan masyarakat setempat berdasarkan asal-usul dan adat istiadat setempat yang diakui dan dihormati dalam sistem Pemerintahan Negara Kesatuan Republik Indonesia.

Dengan demikian suatu pemerintahan kampung memiliki power dalam mengatur pemerintahannya sendiri sesuai dengan perencanaan yang disusun menurut kebutuhan pemerintah di kampung. Jika ada sebagian masyarakat hanya dapat berpartisipasi melalui kontribusi biaya maka yang lainnya dapat memberikan kontribusi berupa tenaga atau pemikiran. Setiap pihak harus memahami akan kekurangan dan keterbatasan masing-masing sehingga dapat saling melengkapi kekurangan masing-masing, baik itu pemerintah dengan masyarakatnaya ataupun antara masyarakat yang satu dengan kelompok masyarakat lainnya.

\section{Terwakilan Stakeholder Dalam Perencanaan Partisipatif}

Partisipasi masyarakat merupakan modal utama dalam upaya mencapai sasaran program pemerintah diseluruh wilayah Indonesia. Keberhasilan dalam perencanaan sasaran pelaksanaan program atau kegiatan pembangunan bukan semata-mata didasarkan pada kemampuan aparatur pemerintah, tetapi juga berkait dengan upaya mewujudkan kemampuan dan keamanan masyarakat untuk berpartisipasi dalam pelaksanaan program pembangunan. Perlunya keterlibatan masyarakat ini dianggap sangat penting, kerena pembangunan yang terlalu menekankan peran pemerintah bercirikan top down mendapat kritikan tajam, dimana kurang peka terhadap kebutuhan lokal. Konteks pelaksaan pembangunan kampung-kampung di Distrik Kombut Kabupaten Boven Digoel Provinsi Papua partisipasi masyarakat sangat penting diperlukan dengan dukungan lembagalembaga non formal (toga, tomas, lembaga sosial kemasyarakatan) sangatla penting guna membantu tercapainya pelaksanaan program pembangunan, sehigga akan muncul satu program atau kegiatan dari prakarsa dan swadaya sera gotong royong dari masyarakat. Atas dasar inilah kesadaran dari masyarakat perlu 
ditumbuhkan dan dtingkatkan sehingga nantinya partisipasinya akan dirasakan masyarakat bersumber dari kesadaran masyarakat itu sendiri secara spontan. Ukuran-ukuran yang dibuat dalam memaknai fenomena partisipasi masyarakat diambil dari beberapa ukuran antara lain : kesediaan membantu secara fisik sesuai kemampuan, membantu secara materi dan membantu secara moril dalam bentuk sumbangan pemikiran, informasi dan saran.

Hal ini juga sesuai dengan teori yang disampaikan Basrowi yang dikutip Siti Irene Astuti D (2011: 58), menjelaskan partisipasi masyarakat dilihat dari bentuknya dapat dibedakan menjadi dua, yaitu: (a) Partisipasi fisik adalah partisipasi masyarakat (orang tua) dalam bentuk menyelenggarakan usaha-usaha pendidikan, seperti mendirikan dan menyelenggarakan usaha sekolah; (b) Partisipasi non fisik adalah partisipasi keikutsertaan masyarakat dalam menentukan arah dan pendidikan nasional dan meratanya animo masyarakat untuk menuntut ilmu pengetahuan melalui pendidikan, sehingga pemerintah tidak ada kesulitan mengarahkan rakyat untuk bersekolah.

Berkait dengan hal tersebut menurut teori partisipasi Fasli Djalal dan Dedi Supriadi, (2001: 201-202) menjelaskan partisipasi dapat juga berarti bahwa pembuat keputusan menyarankan kelompok atau masyarakat ikut terlibat dalam bentuk penyampaian saran dan pendapat, barang, keterampilan, bahan dan jasa. Partisipasi dapat juga berarti bahwa kelompok mengenal masalah mereka sendiri, mengkaji pilihan mereka, membuat keputusan, dan memecahkan masalahnya. Menurut I Nyoman Sumaryadi, (2010: 46), mengemukakan bahwa Partisipasi berarti peran serta seseorang atau kelompok masyarakat dalam proses pembangunan baik dalam bentuk pernyataan maupun dalam bentuk kegiatan dengan memberi masukan pikiran, tenaga, waktu, keahlian, modal dan atau materi, serta ikut memanfaatkan dan menikmati hasil -hasil pembangunan. Salah satu ciri dari suatu daerah yang sudah maju dan mandiri adalah terciptanya peran serta dari semua pihak yang tinggi kesadaranya, serta semakin tanggap dan kritis terhadap segala hal yang menyangkut kehidupannya. Teori partisipasi masyarakat menurut Sudriamunawar (2006:54) menyatakan :

Bahwa keberhasilan penyelenggaraan pembangunan nasional menuntut adanya partisipasi masyarakat, karena partisipasi masyarakat akan menunjang dalam pengelolaan potensi daerah, sehingga proses pembangunan akan berjalan secara berdaya guna dan berhasil guna.

Pemikiran secara sederhana, partisipasi semua pihak adalah peran serta atau keikutsertaan semua pihak dalam awal proses perencanaan sampai pada tahap pelaksanaan diperlukan untuk mendorong masyarakat mau turut serta 
secara bersama-sama dalam proses penyusunan program atau kegiatan pembangunan agar kebutuhan lokal dapat terakomodit dalam kegiatan yang akan dilaksanakan di kampung-kampung di Distrik Kombut Kabupaten Boven Digoel. Mendorong, bukan mengharuskan masyarakat dalam berpartisipasi, tidak cukup dengan dikatakan bahwa karena pembangunan itu untuk masyarakat, maka masyarakat akan mengikuti, tetapi mendorong semua pihak untuk mampu menjelaskan arti pentingnya pembangunan dan manfaatnya buat masyarakat. Pengelaman pembangunan membuktikan bahwa seringkali pembangnan yang diatasnamakan masyarakat dengan pendekatan perencanaan perspektif daerah ternyata tidak sesuai dengan harapan rakyat. Hal ini sebagaimana terlihat dari potret pembangunan pasar distrik kombut yang tidak pernah dipakai masyarakat dalam menjual hasil pertanian dan buruan mereka.

Kesediaan masyarakat untuk berpartisipasi dalam penyelenggaraan program atau kegiatan yang sudah disepakati bersama adalah merupakan indikasi adanya modal awal dari masyarakat untuk berkembang secara mandiri. Dalam hubungan dengan teori partisipasi menurut Tjokroamidjojo (1993:207) mengemukakan bahwa :

Keterlibatan aktif atau partisipasi masyarakat tersebut dapat berarti keterlibatan dalam proses penentuan arah, strateggi dan kebijakan pembangunan yang dilakukan pemerintah.

Berdasarkan uraian diatas maka dapat dijelaskan bahwa masyarakat Distrik Kombut telah ikut berpartisipasi didalam pembangunan. Hal ini dapat dikatakan demikian karena berdasarkan hasil pengamatan penulis masyarakat dapat diajak untuk kerjasama menyusun program atau kegiatan-kegiatan yang dituangkan dalam Rencana Pembangunan Jangka Menengah Kampung (RPJMK) yang dikerjakan secara bersama-sama aparat kampung dengan semua tokoh masyarakat, pemuda dan agama secara bersama-sama menyusun program kerja masing-masing kampung selama lima tahunan. Teori yang disampaikan Sudriamunawar (2006:49) menyebutkan bahwa partisipasi dalam prakteknya mengandung beberapa pengertian yaitu (1) Keterlibatan dalam proses; penetuan arah strategi dan kebijakan pembangunan yang dilakukan pemerintah; (2) Keterlibatan dalam memikul beban dan bertanggung jawab dalam pelaksanaan kegiatan pembangunan; (3) Keterlibatan memetik hasil dan manfaat pembangunan secara adil dan merata.

Pelaksanaan Program strategis pembangunan kampung didasarkan pada IMPRES Nomor 5 Tahun 2007, tentang Percepatan Pembangunan bagi Provinsi Papua dan Papua Barat, tersebut diatas kemudian ditindaklanuti dengan 
Keputusan MENDAGRI RI Nomor 414 tahun 2012, Penetapan Pengurusan Anggaran/Barang dan Pejabat Penerimaan Negara. Kegiatan Urusan Bersama Program Nasional Pemberdayaan Masyarakat. Namun demikian secara operasional di lapangan belum adanya petunjuk teknis tentang Program strategis pembangunan kampung dalam pemberdayaan masyarakat, sesuai dengan amanat undang-undang tersebut diatas, maka pelaksanaan di daerah mengacu pada Undang-Undang Nomor 21 Tahun 2001, tentang Otonomi Khusus bagi Provinsi Papua serta peraturan Gubernur Nomor 79 Tahun 2007, tentang Penyelenggaraan Pemerintah Kampung.

\section{KESIMPULAN}

1. Dalam pengidentifikasian masalah dilapangan, terlihat Partisipasi masyarakat dapat dikatakan baik yakni masyarakat telah peka terhadap fenomena serta realita yang sedang terjadi disekitar mereka, bahkan telah memberikan masukan kepada pihak pemerintah akan hal tersebut.

2. Pelaksanaan perencanaan pembangunan tingkat kampung lebih banyak dilakukan secara formatif dan tidak semua komponen stakeholder dilibatkan secara utuh dalam pelaksanaan musyawarah tingkat kampung. Pihak pemerintah daerah terlihat sangat mendominasi dalam menetapkan program atau kegiatan di tingkat kampung. Hal ini disebabkan lebih pada terbatasnya sumber daya manusia di tingkat kampung.

3. Dalam tahap implementasi pembangunan infrastruktur, masyarakat terkadang berpartisipasi hanya karena ada pendapatan atau upah yang didapat, hal ini terlihat wajar namun juga sekaligus memprihatinkan, disisi lain pemerintah dianggap gagal dalam meningkatkan partisipasi masyarakat.

4. Tingkat pengawasan atau evaluasi masyarakat terhadap pemerintah dalam pelaksanaan pembangunan masih rendah, masih banyak masyarakat yang bermasa bodoh atau tidak ingin mengetahui laporan dari pemerintah, mereka hanya tahu adalah hasil dari pembangunan itu sendiri.

\section{DAFTAR PUSTAKA}

Moleong, Lexy J. 2002. Metode Penelitian Kualitatif. Penerbit PT Remaja Rosdakarya. Bandung.

Millan Friedman,1969. Peranan Kebijaksanaan Moneter. American Economic Review, Maret 1968. Reprinted in Chicago.

Khairuddin. 1992. Pembangunan Masyarakat. Tinjauan Aspek; Sosiologi, Ekonomi, dan Perencanaan. Liberty. Yogyakarta. 
Sa'id, G dan Intan, A.H. 2001. Manajemen Agribisnis. Ghalia Indonesia.

Bintoro, TjokroAmidjojo. 1985; Perencanaan Pembangunan, Penerbit PT Gunung Agung - Jakarta

Siagian, S. P. (2008). Filsafat Administrasi (edisi revisi). Jakarta: Bumi Aksara.

Pasolong, Harbani. (2007). Teori Administrasi Publik. Makasar: Alfabeta

Keban, Y. 2008. Enam Dimensi Strategis Administrasi Publik. Konsep, Teori Dan Isu. Cetakan Kedua. Yogyakarta : Gava Media.

Meriam Budiarjo, 2008, Dasar-Dasar IImu Politik, Gramedia Pustaka Utama, Jakarta

Parson,W. 2008. Public Policy. Pengantar Teori dan Praktik Analisis Kebijakan. Wibowo T (penerjemah). Judul asli: Public Policy: An Introduction to the Theory and Practice of Policy Analysis. Jakarta. Prenada Media Group.

John M. Echols \& Hasan Shadily, 2000, Kamus Inggris Indnesia, Jakarta Gramedia

I Nyoman Sumaryadi. (2010). Efektifitas Implementasi Otonomi Daerah. Jakarta: Citra Utama

Moleong ,Lexy. 2000. Metodelogi Penelitian Kualitatif, bandung: PT, Remaja Rosdakarya.

Fasli Jalal dan Dedi Supriadi. 2001. Reformasi Pendidikan Dalam Konteks Otonomi Daerah. Yogyakarta : Adicita Kurniawan. 2005. Transformasi Pelayanan Publik. Yogyakarta : Pembaruan

H.A.R.Tilaar, 2009, Kekuasaan dan pendidikan : Kajian Manajemen Pendidikan Nasional dalam pusaran kekuasaan, Jakarta, Rinika Cipta

Siti Irene Astuti D 2011, Desentralisasi dan Partisipasi dalam pendidikan, Yogyakarta, UNY

Michael P. Todaro, 1983, Ekonomi Pembangunan di Dunia ketiga, terjemahan Mursid, Penerbit Balai Aksara, Jakarta

Michael, Todaro, 2000, “Pembangunan Ekonomi Dunia Ketiga”, Erlangga, Jakarta

Moh. Farid dan Noora Fithriana, 2016, Implementasi Kebijakan Musyawarah Erencanaan Pembangunan (Musrenbang) Kabupaten Sumenep, Jurnal IImu Sosial dan IImu Politik ISSN. 2442-6962 Vol. 5, No. 2

Fathurrahman Fadil, 20013, Partisipasi Masyarakat Dalam Musyawarah Perencanaan Pembangunan Di Kelurahan Kotabaru Tengah. Jurnal IImu Politik dan Pemerintahan Lokal, Volume II Edisi 2, Juli-Desember 2013

Ita Puspita Sari, 2016, Implementasi Pembangunan Partisipatif (Studi Kasus Di Kelurahan Andowia Kabupaten Konawe Utara), urnal Ekonomi (JE) Vol .1(1), April 2016 E-ISSN: 2503-1937

Sopanah Widyagama Malang (tanpa tahun) Ceremonial Budgeting Dalam Perencanaan Penganggaran Daerah: Sebuah Keindahan Yang Menipu. Jurnal Online 